\title{
WEBSITE USABILITY IN THE DESIGN THINKING METHODIC
}

\author{
MICHAŁ NOWAKOWSKI ${ }^{1}$ \\ University of Szczecin \\ ${ }^{1}$ e-mail: michal.nowakowski@wneiz.pl
}

KEYWORDS

ABSTRACT
Design Thinking methodic, website usability, interactive service

The article presents the Design Thinking methodic as a modern approach of business problems solving by understanding users needs and looking for the best solutions to meet their requirements. The main goal of the Design Thinking is creating solutions which integrate human needs, business requirements and technological opportunities. The publication includes characteristics of the Design Thinking methodic, individual elements and steps of performing. The different phases of the methodic were described in the article on the example of the innovative usability deployment to existing website. Application of the Design Thinking methodic in the areas of both business and entertainment can greatly lead to the improvement of the quality of websites and various interactive services.

\section{The Design Thinking concept}

The Design Thinking methodology is a way to solve a variety of business problems in the way like the designer solves the problem of project (Bell, 2008). This methodic is generally defined as analytical and creative process which engaging the attention and participation of people allows for wide experimentation and creating of models prototypes in order to collect information about them and their improvement (Owen, 2007). The Design Thinking in practice is 
a design process carried out by a team of people with different experience and skills which puts human in the spotlight (e.g. client, user) and specific benefits for him. This process is carried out in stages, it involves putting and frequent testing of hypotheses, building prototypes and gather opinions from recipients. Thus the Design Thinking is a creating method of innovative products and services based on deep understanding of the problems and users needs (Ambrose, Harris, 2010; http://designthinking.pl/co-to-jest-design-thinking).

The Design Thinking also assumes equal relationship between the creator and the user, which is based on mutual understanding and the pursuit of mutual benefits. Besides it focuses on the recipient in order to understand the conscious and unconscious needs. Thanks to the activities in the multidisciplinary team it is possible to look at the problem from multiple perspectives. Experimentation and frequent testing of hypotheses helps to build prototypes and gathering feedback from users. As a result, the solutions are created that are desired and expected by the users, technologically workable and economically profitable (Ambrose, Harris, 2010; Stanford Design Thinking Model, 2015).

This methodology can be successfully used by companies, corporations, foundations, schools or other institutions. It is intended for all organizations that are seeking innovations or new ways to implement the original solutions based on deep identified needs of users. Therefore, it has many applications particularly where, there are problems that do not have only one and the obvious solution (Bell, 2008). Examples of tasks which can be carried out using the Design Thinking methodology are the following e.g. transport of large groups of workers in industrial plants, improving the flow of information in the office or facilitating the use of Internet service.

\section{The Design Thinking phases}

The main goal of the Design Thinking methodic is creating and implementing innovative solutions, innovative technologies, services, strategies, processes, educational programs and even business models.

The first step of the methodic application is to build the most interdisciplinary team, which includes specialists capable to look at the problem from different technical, scientific and psychological perspectives. In such a team can be found both engineers, technologists, marketing specialists, designers and sociologists. So called team realizes, step-by-step method stages using a set of tools and techniques to develop implementable solution. The main objective of the team is to create original solution and check its operation at the stage of prototyping. The path leads through the following stages does not have to be linear, because deficiencies incurred during prototyping may need to return to the stage of ideas generating or earlier to define the problem and start the process from the beginning (Bell, 2008; Owen, 2007).

The second step of the Design Thinking working is to carry out five key phases characteristic for these methodic: empathy, defining the problem, ideas generating, prototypes building and testing (Stanford Design Thinking Model, 2015). The phases of the Design Thinking methodic are described below. 


\section{Phase 1-Empathy}

The process of building innovation begins with empathy. The first stage of the Design Thinking is deep understanding of user needs and problems. The key is to recognize hidden and intuitive motivations, which influence people's choices and behaviors. An important issue at this stage is to place in the role of the user, thinking of his course, speaking his words, looking at what he does and what are his habits, what he likes and what he feels. It must be remembered not to judge, criticize or generalize views about the user (Owen, 2007; Stanford Design Thinking Model, 2015).

Tools useful at this stage may include empathy maps, ethnographic interviews, users observations, reconnaissance surveys with an accurate analysis of the environment and needs in terms of functionality. In addition discreet observation of behaviors can show that users often use self invented improvements that can be an inspiration for new products.

\section{Phase 2 - Defining the problem}

At this stage, the project team analyzes information collected during the phase of empathy in order to define the real problem and user needs. This stage requires breaking of thought structures and habits that typically reduce the field of vision. Defining the problem dramatically influences on the future direction of sought solutions. This stage is usually a huge challenge, because most people prefer to work immediately on a specific solution, not to move in the uncertainty of many possible directions. Unfortunately, too quick definition of the problem restricts the full picture of the situation, as it may be, that invested money, time and energy do not relate to the real problem. Keep in mind that a well-formulated problem should meet the following criterions: it should be clearly defined, it should not be a solution, it should be so specific that it can be evaluated and verified and it should be designed for a specific person or a small group of people (Owen, 2007; Stanford Design Thinking Model, 2015).

Tools useful at this stage may include method of creative problem solving or technique of " $5 \times$ why".

\section{Phase 3 - Ideas generating}

At this stage, the team is focused on generating as many possible solutions for the defined problem, therefore it is the most creative step of the Design Thinking method. This requires not only a strong substantive knowledge, but above all the courage in the creation of new and unconventional solutions and also evaluation and critique abstaining of other team members ideas. The stage should be completed on assessment and democratic choice of the best idea on the basis of which the prototype will be created (Owen, 2007; Stanford Design Thinking Model, 2015).

The main tool at this stage is brainstorming. It is good to remember that the brainstorming method is not an aim in itself, but only the starting point to determine further directions of actions. The main challenge here is respecting basic principles, like: offering even the most craziest solutions, not assessing, building on the ideas of others, not too much getting used to own ideas or not focusing only on restrictions. It should also keep in mind about additional assumptions related to the time limit, the amount of ideas or choice of moderator supervising compliance with 
the rules required a good brainstorm. The result of working with this method should be selection of few ideas, which then are dedicated for prototyping.

\section{Phase 4 - Prototypes building}

At this stage, few ideas worth of developing are selected, and then the most physical forms of these solutions are built, which will be used to form the prototype. The purpose of prototypes is not to create complicated models with characteristics similar to the final product, but creating something on shape of the product, what can be quickly constructed manually. The most important here is the ability to visually present the idea to users and to have rapid feedback about the solution. It is better to quickly find out, that the idea differs from the real needs and change the direction, rather than go further into increasingly costs of building something useless. Providing feedback from other project participants and potential users leads to idea improvements and creates a unique opportunity to hear the comments, which usually bring very much to the primary concept. Though never can be sure to the end, that the final product will be a success, but frequent building of improved prototypes, putting them into the users hands and listening to what they have to say is reducing significantly the risk of final failure (Owen, 2007; Stanford Design Thinking Model, 2015).

To build rapid prototypes it can be used a variety of tools, such as paper based materials, carton, drawstring, wood, polystyrene foam or anything else, that physically show the target product. However, the prototype does not always have to be an object, because in the case of services, it can be used the storyboard or the user's path drawing. The main thing is to do something more than just only a verbal description and in any way to visualize the analyzed idea.

\section{Phase 5 - Testing}

The process of building the innovation ends up of the prototype testing and improving. At this stage is followed the assessment of each prototypes by the group and the selection of the one, which received the most appreciation of the whole team. Once again users are asked for feedback and the whole process can be repeated until it reaches a satisfactory level of implementation of the selected prototype. Then, the selected solution is tested in a real environment in which the product will be used. What is important is to determine the required parameters to clearly determine the outcome of conducted tests. After testing ended on a positive result it can be talked, that the product or service are ready for the final implementation. Testing phase requires the commitment of many parties and support from the technical, formal, administrative and legal (Owen, 2007; Stanford Design Thinking Model, 2015).

Unfortunately, this phase is often ignored in the implementation of many projects, what causes, that the seemingly good ideas and solutions are implemented directly into everyday use, and only there it turns out that they do not meet the required assumptions and expectations of the audience. 


\section{The wehsite usability}

Usability is a property of products decides about them quality for use. Usability is also the science of interactive devices ergonomics and electronic applications.

Website usability determines the range to which the service can be used by specified users to achieve specified goals within a specified context of use. The usability concept is usually used in relation to websites ergonomics and software applications. The usability in practice is a branch of science dedicated to comfort and ergonomics of using websites and web applications. The usable website is a site, that at the first visit is attracted the attention of visitors, and upon further browsing allows intuitive use of its resources (Krug, 2006; Nielsen, 2003).

On the website usability have influence a number of factors, like the following: website pages first impression, clearly defined purpose and characteristic of website, graphic service content, text service content, speed of pages loading, information organization in service, hierarchy of information in service, clear and predictable service navigation, ease of finding information, presence of the help system, compliance with the standards of web design and syntax correctness of the used programming language (Kalbach, 2008; Krug, 2006; Nielsen, 2006).

\section{The usability conventions on the Internet}

The development of the science of designing useable websites caused formulation of many rules, guidelines, conventions and so-called best practices. It is an attempt to identify and formulate universal laws, respect of which is to ensure the increase of websites usability. These guidelines are derived from the experience of experts and websites research usability.

Standards and conventions are generally accepted norms of behavior and thinking in the environment, which are present in almost every area of life. The main task of conventions used in the Internet is users releasing from having unnecessary thinking, because it is much better for the user to concentrate on the site content than on its form (Krug, 2006; Nielsen, 2003).

Although the best way to provide high usability of designed website is including in its development the target users, that a good knowledge about conventions certainly facilitates the design process, lets to avoid common mistakes and can reduce the costs of future testing process.

Examples of convections used on websites can be included: the header of the page, the caption under a photography, positioning content elements in selected places (e.g. the searching box in the upper right part of the service), the service logotype positioning in the upper left corner of the page, highlighting clickable content elements, changing color of visited links or using the shopping cart in online trade.

\section{The Design Thinking application for wehsite usability improving}

The usability is a very important quality aspect of every working website. As previously described, the website usability depends on many criterions, that make it more functional and easier to use. Implementation of quality principles, conventions and usability criterions for Inter- 
net service can be approached in two ways. The first of them is service designing according to specific rules of quality (like usability, accessibility or correct information architecture) and then its testing, implementing and launching. While this approach should be used as often as possible, especially in the early phases of the service formation, it is often not the case, due to the required additional time and associated costs. Therefore, most often is carried out the alternative way of service implementing to work, so relatively fast visual and functional project, implementation and launching. Of course, the second way allows for more efficient achievement of expected results in the form of working service, but this is mostly paid for big losses on its quality for use. In this situation, verification of required usability aspects should be done on working website and if necessary its re-testing and improving.

As that for this purpose, can be successfully use the Design Thinking methodic in further part of the article, for description of the methodic application procedure, was taken into account the second scenario, which is usability improving of working website. Specified phases of the Design Thinking methodic in terms of usability improvement of any web service were described below.

Phase 1 - Empathy - website usability

At this stage it should be performed the following tasks:

- to gather an interdisciplinary team of experts, which comprised specialists in such areas as: information architecture, usability, graphics, software engineering, presentation and data visualization, marketing, sociology, psychology, etc.;

- to know the user profiles using the service (e.g. age, sex, education, interests, etc.);

- to identify the needs of potential users (e.g. information, functional, service, etc.);

- to identify potential users problems in work with service (e.g. usability problems, errors handling, access to information, etc.);

- to listen and observe users in contact with service and save any comments, observations and suggestions.

Phase 2 - Defining the problem - website usability

At this stage, the main issue should be defined, based on the analysis of collected information in the previous paragraph and from various viewpoints. Assuming that, the main area of the service research is its widely understood usability, can be asked some questions which easily identify the basic problems encountered by users in website. The list of sample questions can be the following:

- Is the service simple and easy on working?

- For what purpose the service should be useable?

- Is the user aware of problems with the service usability?

- Will addition of general usability principles make the service using easier?

- Does the service have correctly defined information architecture?

Phase 3 - Ideas generating - website usability

At this stage, it should be selected the most important problems/topics for improvement, identified in the previous phase and propose various solutions to repair them. As the most of the 
problems in the second phase concerned usability aspects, so that it can be concluded, that this area needs to be improved and to propose for this quality recommendations, which insertion would significantly improve the level of website usability. These recommendations are in most cases usability conventions, which can be divided into several groups, which include specific usability criterions. The names of the groups and assigned to them usability criterions are described below.

Group 1 - Usability recommendations for used layout and resolution on website (Kalbach, 2008; Krug, 2006; Nielsen, 2006):

- using a typical block design for the website (header, navigation, content, footer);

- displaying the entire contents of the page without horizontal scrollbar;

- scrolling average of 2 "screens" down (maximum 4) using vertical scrollbar (if the height of the page is greater than 4 "screens" it can means, that page content should be placed on another page);

- taking into account the principles of so-called responsiveness of the service pages, which is designing the service so that its look and layout adjust automatically to the size of the device window that is displayed (e.g. for browser, smartphone or tablet).

Group 2 - Usability recommendations for used colors on website (Kalbach, 2008; Krug, 2006; Nielsen, 2006):

- appropriate color contrast between the background and content (the best is to present the content of the dark type on a white background);

- appropriate color contrast for information, which should be distinguished;

- the same or similar color schemes for all parts and sections of the website;

- adjusting the service colors for people who have difficulty distinguishing colors or color-blind (for people with such dysfunction combination of red and green is particularly disadvantageous);

- using appropriate messages and information about errors.

Group 3 - Usability recommendations for used typography on website (Kalbach, 2008; Krug, 2006; Nielsen, 2006):

- text in the content should always be darker than the background (standard color of the basic text is black);

- pages with lots of text should avoid dark graphic design;

- it is recommended the fluid text size (relative size), which allows users to change the font size depending on their needs;

- standard font size on websites is 12 points (16 pixels), fonts much smaller and larger than standard should not be used due to the difficulty or decrease its speed in reading;

- color of hyperlinks: standard is blue (for active links) and violet or bright blue (less saturated color for visited links);

- links should be easily identifiable in both the text and beyond;

- it is recommended to use popular fonts that normally should be installed on every operating system; 
- different styles of fonts formatting, such as bold, italic, small caps or other distinctions, should be used alone;

- the first paragraph of the chapter or section should be commenced from the left edge and the indentation is to mark the beginning of the paragraph;

- intervals between successive paragraphs are very important, because they make it clear and separation of the individual paragraphs.

Group 4 - Usability recommendations for used text content on website (Kalbach, 2008; Krug, 2006; Nielsen, 2006):

- creating content concise and on about;

- service language should be adjusted for the needs of recipients;

- sections, categories and headings for the content should be labeled adequate for what value they have for consumers (not for company);

- instead of typing the content of the website it is better to use examples;

- avoiding to use so-called previews;

- avoiding to use instructions.

Group 5 - Usability recommendations for used multimedia content on website (Kalbach, 2008; Krug, 2006; Nielsen, 2006):

- illustrating the content of images for significant value;

- animations should not detract of users and should not be used for key elements of service;

- animations working should depend on users;

- sounds on the website should not be played automatically when entering the site home page;

- sound effects can be applied to the functional elements of the website (e.g. in navigation, communication errors, etc.).

Group 6 - Usability recommendations for used navigation systems on website (Kalbach, 2008; Krug, 2006; Nielsen, 2006):

- application of conventions to navigation systems greatly simplifies navigation within the website, because they determine the appearance and position of navigation elements;

- placing some items in standard locations makes it easy and quick to discover, and unified appearance allows to discriminate them from other elements;

- main navigation area should be placed in an easy to see service place (preferably at the top of the site's pages);

- items in the navigation areas should be grouped in such a way that similar elements should be facing one another;

- uniform appearance of global navigation, which should be in the same place on every page, informs the user that still stays within the same website;

- important element of global navigation is a link to the home page (it makes possible to go to the site home page from any place);

- website logotype applies to the whole of its contents, so it must be on the top of the logical hierarchy and should be a link to the home page; 
- names of the categories and sections (navigation labels) in navigation systems should be easy to understand and distinguish and within the shortest way should describe the content associated with them (use naming conventions);

- order of the sections in the navigation systems should be set so that in the beginning are the ones, that are most commonly used;

- each sections names (references and navigation labels) should accurately reflect the content that is connected with them, and they should be understandable and transparent to users;

- using bookmarks is convention, because they are intuitive to use, they are the distinguishing elements on the page, they are noticed by all users and look good;

- graphic icons in the navigation system should be used as a supplement of the text category name in order to facilitate users to quickly identify classes of items, never as presented alone graphics.

Group 7 - Usability recommendations for used searching systems on website (Kalbach, 2008; Krug, 2006; Nielsen, 2006):

- searching information function (content) is one of the most important functional elements in the service and therefore it should be absolutely accessible, easy to find and use;

- searching function should be accessible from every page of the website, in particular from the home page;

- searching function should search the whole website by default (all information available on the website);

- searching box (text box) should be easily visible, easy to use and have the possibility to enter the searching text (without referring to a special searching page);

- searching box should be complemented by a button, which starts a search process with the respective indication/description, e.g. Search, Go, Find;

- searching button should be placed to the right of the searching box (the simplest and most intuitive solution);

- searching box should have a suitable color, contrasting with the surrounding graphics (preferably white) and width (displaying approx 25-30 typical characters of written text).

Phase 4 - Prototypes building - website usability

At this stage, it should firstly be verified the compliance of each usability criterions listed in the third phase with the facts occurring in the service. Therefore, it would be advisable to check whether selected functions are on the website in general, then what kind of compliance state are they with the usability conventions, and whether is there a need to correct them according to established usability principles. For this purpose, it can be used the results of analyzes on users, collected in the first phase and the opinions of experts from the second and third phase. At the end, a list of criterions that require repair should be created to for each of them could do the prototypes, that could improve the current usability state.

To build prototypes, at the beginning it would be good to use the brainstorming method to the best adjusting the selected usability criterion to the website specification, and then the 
project visualization of the criterion in graphical form using the drawing tools in the traditional and/or electronic form. Just after this actions it should be designed and programmed the selected convention in practice, in order to its implementation and presentation on the website. A similar procedure should be applied in relation to all of the criterions, which needs to be improved or updated.

Phase 5 - Testing - website usability

At this stage, created in the fourth phase prototypes should be tested in terms of functionality and usability, and for compliance with the users requirements and the service specification. In the process of the created prototypes usability testing it can be used various methods of involving users, such as: interviews, observations and registrations, heuristic evaluation, cognitive journey, standards inspection, checklists, eye tracking, A-B testing, load testing or usability testing (Burke, 2005; Hatchuel, 2009; Krug, 2006; Travis, 2003). Prototypes testing phase can be repeated several times until they reach the satisfactory results and user satisfaction.

The result of the prototypes testing should be the choice of one the best or some of the best, and then implementing them in the real environment, where they will be used. In the case of Internet service it will mean an improvement in terms of its usability in aspect of selected and revised usability criterions. It is good to remember, that in order to improve the usability of many criterions at the same time, it may happen a situation that effects of their working can overlap to a certain extent.

\section{Conclusions}

The Design Thinking methodic is a relatively new approach to solve various business problems. However it is procedurally similar to present for a long time life projects phases and cycles, but it differs increased emphasis on improving the performance targets for end-users. It is manifested in the first phase of the method, where the main emphasis is on understanding the needs of potential users through the empathy. Further actions are also subordinated to the needs of target audience, until their complete satisfaction with the tested product. At the present time, this approach is becoming increasingly important in product designing, that is why it can also have a huge impact on changing business processes in enterprises. As a result, this methodic can be used to develop and improve various types of software products, including websites and web applications, as well as to improve their quality aspects.

\section{Bihliography}

Ambrose, G., Harris, P. (2010). Basics Design - Design Thinking, AVA Publishing SA.Szwajcaria.

Bell, S.J. (2008). Design Thinking. Chicago: American Libraries.

Burke, K. (2005). Online A/B Testing. Target Marketing, 28.

Hatchuel, A., Weil, B. (2009). C-K design theory: An advanced formulation. Research Engineering Design, 19. Londyn. Kalbach, J. (2008). Projektowanie nawigacji strony WWW. Optymalizacja funkcjonalności witryny. Gliwice: Wydawnictwo Helion/O’Reilly.

Krug, S. (2006). Nie każ mi myśleć. O życiowym podejściu do funkcjonalności stron internetowych. Wydanie II. Gliwice 
Nielsen, J., Tahir M. (2006). Funkcjonalność stron WWW: 50 witryn bez sekretów. Gliwice: Wydawnictwo Helion. Nielsen, J. (2003). Projektowanie funkcjonalnych serwisów internetowych. Gliwice: Wydawnictwo Helion.

Owen, C. (2007). Design thinking: Notes on its nature and use. Design Research Quarterly.

Stanford Design Thinking Model. (2015). Retrieved from: http://www.stanforddaily.com/what-is-design-thinking.

Travis, D. (2003). E-commerce Usability. Tools and techniques to perfect the on-line experience. Londyn: Taylor \& Francis.

http://designthinking.pl/co-to-jest-design-thinking

\section{UŻYTECZNOŚĆ SERWISU INTERNETOWEGO W METODYCE DESIGN THINKING}

SŁOWA KLUCZOWE

STRESZCZENIE
Design Thinking, użyteczność serwisu internetowego, usługa interaktywna

Artykuł przedstawia metodykę Design Thinking jako nowoczesne podejście do rozwiązywania problemów biznesowych poprzez zrozumienie potrzeb użytkowników i szukanie najlepszych rozwiązań spełniających ich wymagania. Celem Design Thinking jest tworzenie rozwiązań integrujących ludzkie potrzeby, wymagania biznesowe oraz możliwości technologiczne.

Publikacja zawiera charakterystyczne cechy metodyki Design Thinking, poszczególne jej elementy oraz etapy przeprowadzania. W artykule opisano poszczególne fazy metodyki na przykładzie innowacyjnego wdrażania użyteczności do już działającego serwisu internetowego.

Zastosowanie metodyki Design Thinking w obszarach zarówno biznesowych, jak i rozrywkowych, może w dużym stopniu prowadzić do polepszania jakości serwisów internetowych oraz różnego rodzaju usług interaktywnych. 
